\title{
Responsiveness of Lycopersicon pimpinellifolium to acute UV-C exposure: histo-cytochemistry of the injury and DNA damage
}

\author{
M. Iriti ${ }^{1,3}$, S. Guarnieri ${ }^{2}$ and F. Faoro ${ }^{1,3 凶}$ \\ ${ }^{1}$ Istituto di Patologia Vegetale, Università di Milano; ${ }^{2}$ Dipartimento di Scienze e Tecnologie Alimentari e \\ Microbiologiche, Sezione di Nutrizione Umana, Università di Milano; ${ }^{3}$ Istituto di Virologia Vegetale, CNR, \\ Milano, Italy
}

Received: 26 January, 2007; revised: 22 March, 2007; accepted: 24 April, 2007

available on-line: 23 May, 2007

\begin{abstract}
The in vivo and in vitro effects of UV-C $(254 \mathrm{~nm})$ exposure $\left(0.039\right.$ watt $\cdot \mathrm{m}^{-2} \cdot \mathrm{s}$ for $\left.2 \mathrm{~h}\right)$ of currant tomato (Lycopersicon pimpinellifolium), indigenous to Peru and Ecuador, were assayed. $\mathrm{H}_{2} \mathrm{O}_{2}$ deposits, dead cells and DNA damage were localized, 12/24 h after irradiation, mainly in periveinal parenchyma of the 1st and 2nd order veins of the leaves, and before the appearance of visible symptoms, which occurred $48 \mathrm{~h}$ after irradiation. Cell death index was of $43.5 \pm 12 \%$ in exposed leaf tissues, $24 \mathrm{~h}$ after treatment. In currant tomato protoplasts, the percentage of viable cells dropped $1 \mathrm{~h}$ after UV-C irradiation from $97.42 \pm 2.1 \%$ to $43.38 \pm 4.2 \%$. Afterwards, the protoplast viability progressively decreased to $40.16 \pm 7.25 \%$ at $2 \mathrm{~h}$, to $38.31 \pm 6.9 \%$ at $4 \mathrm{~h}$, and to $36.46 \pm 1.84 \%$ at $6 \mathrm{~h}$ after the exposure. The genotoxic impact of UV-C radiation on protoplasts was assessed with single cell gel electrophoresis (SCGE, or comet assay). UV-C treatment greatly enhanced DNA migration, with $75.37 \pm 3.7 \%$ of DNA in the tail versus $7.88 \pm 5.5 \%$ in the case of untreated nuclei. Oxidative stress by $\mathrm{H}_{2} \mathrm{O}_{2}$, used as a positive control, induced a similar damage on non-irradiated protoplasts, with $71.59 \pm 5.5 \%$ of DNA in the tail, whereas oxidative stress imposed on UV-C irradiated protoplasts slightly increased the DNA damage $(85.13 \pm 4.1 \%)$. According to these results, SCGE of protoplasts could be an alternative to nuclei extraction directly from leaf tissues.
\end{abstract}

Keywords: UV-C, currant tomato, comet assay, oxidative stress, protoplasts

\section{INTRODUCTION}

Ultraviolet (UV) light, differently to photosynthetically active radiations (PAR, 400-700 nm), consists of wavelengths between 200 and $400 \mathrm{~nm}$, and it is subdivided into UV-A (315-400 nm), UV-B (280-315 nm) and UV-C (200-280 nm) radiations. Most of them are potentially hazardous to living organisms, particularly UV-C, that has the shortest wavelengths and the highest energy. The biological effects of UV light are due to photochemical reactions, because of large quanta involved in its emission and absorption (Coohill, 1989). Therefore, highly energetic UV photons are able to destroy chemical bonds of biomacromolecules, leading to an array of cell injuries (Stapleton, 1992). In particular, lipid peroxidation and membrane damage impair transport systems, as well as the alteration of aminoacid residues and the inactivation of whole proteins and enzymes, i.e. ribulose-1,5-bisphosphate carboxylase and subunits of photosystem I and II, decrease the photosynthetic efficiency. Furthermore, the most important cellular target site of exposure to UV radiation is DNA, resulting in DNA photoproducts and mutations (reviewed in Hollósy, 2002).

Although the very dangerous UV-C are not physiologically relevant, being blocked by the ozone layer in the stratosphere, they have been used to study DNA damage, as their photoproducts are the

Corresponding author: F. Faoro, Istituto di Patologia Vegetale, Università di Milano, via Celoria 2, 20133, Milano, Italy; fax: (39 02) 503 16781; e-mail: f.faoro@ivv.cnr.it

Abbreviations: DAB, 3,3'-diaminobenzidine; DAPI, 4',6-diamidino-2-phenylindole; FDA, fluorescein diacetate; PBS, phosphate-buffered saline; SCGE, single cell gel electrophoresis 
same as those induced by UV-B radiation reaching the Earth surface (Cleaver, 2006). In particular, it has been shown that UV-C can induce programmed cell death (PCD) both in animal and in plant cells (Danon \& Gallois, 1998).

Plant defence response to UV light includes protective structures and mechanisms. Protective structures in epigeous organs are mainly physical barriers, consisting of epidermal appendages, such as hairs and glandular trichomes secreting UV-absorbing compounds. Epicuticular waxes and cutin are able to intercept and modify the incident radiation, as well as leaf surface reflectance that may be effective in some plants. The protective mechanisms, include mainly antioxidant defence, both enzymatic (superoxide dismutase, catalases, ascorbate peroxidase, peroxidases, glutathione $S$ methyltransferase and enzymes of the Halliwell-Asada cycle) and non-enzymatic (ascorbic acid, glutathione, tocopherols, carotenoids, $\mathrm{N}$-acetylcysteine, flavonoids and polyamines), besides the specific repair machineries for DNA and photosynthetic apparatus damage (reviewed in Kovács \& Keresztes, 2002).

Within the genus Lycopersicon, currant tomato (Lycopersicon pimpinellifolium), a wild tomato little changed by domestication, has been studied for many purposes. It has been introduced in breeding programmes, to transfer into different crops the resistance to tomato yellow leaf curl virus (TYLCV), to the fungus Cladosporium fulvum and to the nematode Globodera rostochiensis (Jung et al., 1998; Pico et al., 1999; de Wit et al., 2002), and to increase tomato fruit hexose content (Husain et al., 2001).

We previously reported the potential role of currant tomato as an ozone bioindicator, because of its high sensitivity to this pollutant (Iriti et al., 2006). We also correlated this sensitivity to the large amount of $\mathrm{H}_{2} \mathrm{O}_{2}$ induced by ozone oxidative stress in leaf tissues, possibly due to poor antioxidant defences (Iriti et al., 2006). In an attempt to further elucidate L. pimpinellifolium response to oxidative stress, we assayed its sensitivity to a different environmental factor, UV-C, both in vivo an in vitro, using a protoplast system. The leaf tissue responsiveness was examined by a histo-cytochemical approach, and the injury due to radiation was correlated to DNA damage assessed by single cell gel electrophoresis (SCGE). SCGE, also known as comet assay, allows the detection of DNA damage, including denaturation, single and double strand breaks, incomplete excision repair sites, base modifications, alkali labile apurinic and apyrimidinic sites and DNA crosslinks due to genotoxic agents, such as radiation, chemicals, environmental pollutants and contaminants (Navarrete et al., 1997; Palyvoda et al., 2003).

We show here that currant tomato appears to be sensitive to UV-C in the same way as to ozone, responding with an oxidative burst leading to programmed cell death. We also show for the first time that UV genotoxicity in a plant can be detected by SCGE.

\section{MATERIALS AND METHODS}

Plant material and protoplast isolation. Seeds of currant tomato (Lycopersicon pimpinellifolium Mill.) were planted in a standard compost in seed trays and raised in a conditioned glasshouse, under a 16-h photoperiod at $20-25^{\circ} \mathrm{C}$ for 2 weeks, then transferred to $13-\mathrm{cm}$ pots and grown in the same conditions for further 2-3 weeks. At this growth stage, plants (15$20 \mathrm{~cm}$ tall) had developed 5-6 pinnately compound leaves and were irradiated.

Currant tomato protoplasts were isolated from 3-week-old seedlings. Fully expanded leaves were dusted with carborundum (600 mesh) and gently washed with sterilized water. Leaf fragments of approx. $2 \mathrm{~cm}^{2}$ were excised and floated in an enzyme mixture of $2 \%$ cellulase Onozuka R-10 and 0.5\% macerozyme Onozuka in $0.55 \mathrm{M}$ mannitol, pH 5.8, and incubated overnight at $25^{\circ} \mathrm{C}$ in a rotary shaker at 10 r.p.m. Incubated material was passed through a $60 \mu \mathrm{m}$ nylon filter and the resulting suspension centrifued at $100 \times g$ for $5 \mathrm{~min}$. The pelleted protoplasts were washed in $0.55 \mathrm{M}$ mannitol and finally resuspend gently at a density of $5 \times 10^{5}$ per $\mathrm{mL}$, as measured by drawing $6.6 \mu \mathrm{L}$ of the sample by capillarity into a KOVA ${ }^{\circledR}$ Glasstic $^{\circledR}$ Slide 10 with Grid Chamber (Hycor Biomedical Ltd, UK) and examined with a light microscope.

UV irradiation. Ultraviolet light was provided by a Universal-UV-Lampe $220 \mathrm{~V}, 50 \mathrm{~Hz}$ (CAMAG, Muttenz-Schweiz) (Buschmann et al., 2000). Leaf fragments $(1.5 \times 1.5 \mathrm{~cm})$ were floated individually in sterile distilled water in a cell culture multiwell dish $(252 \times 2 \mathrm{~cm}$ wells $)$. Aliquots $(0.5 \mathrm{~mL})$ of protoplast suspension were placed into flat-bottom glass vials (21 $\mathrm{mm}$ in diameter). Leaf fragments and protoplasts were irradiated in the UV-C region of the UV light, at the wavelength of $254 \mathrm{~nm}$, for $2 \mathrm{~h}$. The irradiance, i.e. the instantaneous intensity of UV incident on a surface, was of 0.039 watt $\cdot \mathrm{m}^{-2} \cdot \mathrm{s}$, as measured by a radiometer.

Histo-cytochemistry. Cell viability was assessed with Trypan blue (Sigma, USA) in leaf tissues, and with fluorescein diacetate fluorochrome (FDA, Molecular Probes, Inc., Eugene, OR, USA) in protoplasts. Hydrogen peroxide deposits were localized with 3,3'-diaminobenzidine (DAB, Sig$\mathrm{ma}$ ) in leaf fragments, whereas nuclear viability was assayed with 4',6-diamidino-2-phenylindole (DAPI) fluorochrome stain (Sigma, USA) in both systems. Trypan blue and DAB staining was carried out as previously reported (Iriti \& Faoro, 2003). 
FDA staining was performed as follows: $40 \mu \mathrm{L}$ from $0.2 \%(\mathrm{w} / \mathrm{v})$ stock solution of FDA in acetone, stored at $-20^{\circ} \mathrm{C}$, was added into $7 \mathrm{~mL}$ of 0.55 $\mathrm{M}$ mannitol, and this staining solution was mixed 1:1 with protoplast suspension.

DAPI dye was dissolved in water or $0.55 \mathrm{M}$ mannitol at $0.1 \mathrm{mg} / \mathrm{mL}$ for tissue and protoplast nuclear staining, respectively.

Protoplast viability and cell death assessment. Protoplast viability was determined by the FDA vital dye, at $0,1,2,4$ and $6 \mathrm{~h}$ after irradiation. At least 500 protoplasts were counted in three replicate slides for each time. Non-viable protoplasts were FDA-negative, and appeared red because of chlorophyll autofluorescence, whereas the viable ones were FDA-positive (green-yellow).

Dead cells in leaf tissue fragments were evaluated according to "cell death index" by image analysis, as previously reported (Faoro \& Iriti, 2005), i.e. the percentage of blue pixels (Trypan blue positive cells) in respect to the total image ones.

Evaluation of protoplast DNA resistance to oxidative damage: comet assay. Fully frosted microscope slides (Richardson Supply Co., London, UK) were precoated with $1.5 \%$ normal melting point agarose. The suspension of protoplasts was mixed with $1 \%$ low melting point agarose, layered on the slide and covered with the coverslips. A final layer of low melting point agarose was added and the slides were kept on ice for $5 \mathrm{~min}$. Afterwards, the slides were dipped into a lysis buffer $(2.5 \mathrm{M} \mathrm{NaCl}, 0.1 \mathrm{M}$ $\mathrm{Na}_{2}$ EDTA, $10 \mathrm{mM}$ Tris, $1 \%$ Triton $\mathrm{X}-100,1 \%$ dimethyl sulfoxide, $\mathrm{pH} 10$ ) and kept at $4^{\circ} \mathrm{C}$ for $2 \mathrm{~h}$ in the dark. They were then placed in a fresh alkaline electrophoresis buffer $\left(0.3 \mathrm{M} \mathrm{NaOH}, 1 \mathrm{mM} \mathrm{Na} \mathrm{N}_{2}\right.$ EDTA) in a horizontal electrophoresis tank (Scotlab, Coatbridge, UK) at $4^{\circ} \mathrm{C}$ for $40 \mathrm{~min}$ for DNA unwinding, followed by $30 \mathrm{~min}$ of electrophoresis at $4^{\circ} \mathrm{C}(25 \mathrm{~V}$, $300 \mathrm{~mA}$ ).

The slides were subsequently neutralised $(0.4$ $\mathrm{M}$ Tris/ $\mathrm{HCl}, \mathrm{pH}$ 7.5), stained with ethidium bromide (2 mg/L) in neutralising buffer, washed with PBS, drained and covered with coverslips.

Fifty cells on each slide were electronically captured with an epifluorescence microscope with an excitation filter of 330-385 $\mathrm{nm}$ (barrier filter 420 $\mathrm{nm}$ ). A computerised analysis system (Image-pro plus 5.1, Media Cybernetics, USA) allowed the fluorescence intensity to be quantified.

Undamaged DNA appeared as a fluorescent core, whereas strand breaks in the chain led to the appearance of a tail. DNA damage was expressed as percentage of DNA (measured as fluorescence) in the tail.

Microscopy. Fluorescence and light microscopy was performed by an Olympus BX 50 light microscope (Olympus, Tokyo, Japan), equipped with epipolarization filters and differential interference contrast (DIC), to improve contrast when necessary. Trypan blue and DAB stained samples were observed via light absorption: dead cells stained blue and $\mathrm{H}_{2} \mathrm{O}_{2}$ was visualized as reddishbrown precipitate. DAPI samples were examined with the UV light, exciter filter 330-385 nm, barrier filter 420. Nuclei of damaged protoplasts were bright blue. Blue light (exciter filter 450-490 $\mathrm{nm}$, barrier filter $515 \mathrm{~nm}$ ) was employed for FDA dye.

Statistical analysis. Each experiment was repeated at least three times. All the data were reported as mean \pm S.D. For comet assay, statistical analysis was performed with Duncan test, to compare control values with all treatments. A $P^{*}<0.05$ was considered as statistically significant.

\section{RESULTS}

\section{UV-C irradiation of leaves}

In a set of preliminary experiments, currant tomato plants were exposed to a range of UV-C acute doses. Leaf fragments excised from 3-weekold plants were treated with a UV-C irradiance of 0.039 watt $\cdot \mathrm{m}^{-2}$. $\mathrm{s}$ for $0.5,1,1.5,2$ and $2.5 \mathrm{~h}$, and tissue damage was checked up to $48 \mathrm{~h}$ after irradiation with the aid of a stereomicroscope. Among these different doses, the $2 \mathrm{~h}$ exposure was selected for the subsequent in vivo experiments, being the minimum dose causing the appearance of visible symptoms within 2 days. After a $2 \mathrm{~h}$ exposure visible symptoms became appreciable in the adaxial leaf surface about $48 \mathrm{~h}$ later, as small necrotic spots scattered on the lamina (not shown). However, early injuries were detected at the microscopic level already $12 \mathrm{~h}$ after UV-C treatment. At this time, bleaching and chlorosis occurred nearby the major leaf vein (Fig. 1A), extending to 2nd order veins (Fig. 1B) in further $12 \mathrm{~h}$. Interveinal areas of treated tissues did not appear damaged, neither did the control leaf fragments (Fig. 1C).

Detection of dead cells performed with the Trypan blue vital exclusion dye (Fig. 2A) showed that in tissues treated with UV-C for $2 \mathrm{~h}$ almost half of the mesophyll palisade cells were stained within $24 \mathrm{~h}$ after the exposure. The cell death index, estimated by image analysis, was $43.5 \pm 12.2 \%$, corresponding to approx. $55 \%$ dead cells per $\mathrm{cm}^{2}$ of leaf mesophyll tissue. Leaf fragments from non-irradiated controls appeared unstained (Fig. 2B).

Further microscopic examinations revealed the presence of $\mathrm{H}_{2} \mathrm{O}_{2}$ deposits, as DAB brownish precipitates, mainly in periveinal mesophyll cells of the 1st and 2nd order veins (Fig. 2C), $12 \mathrm{~h}$ af- 

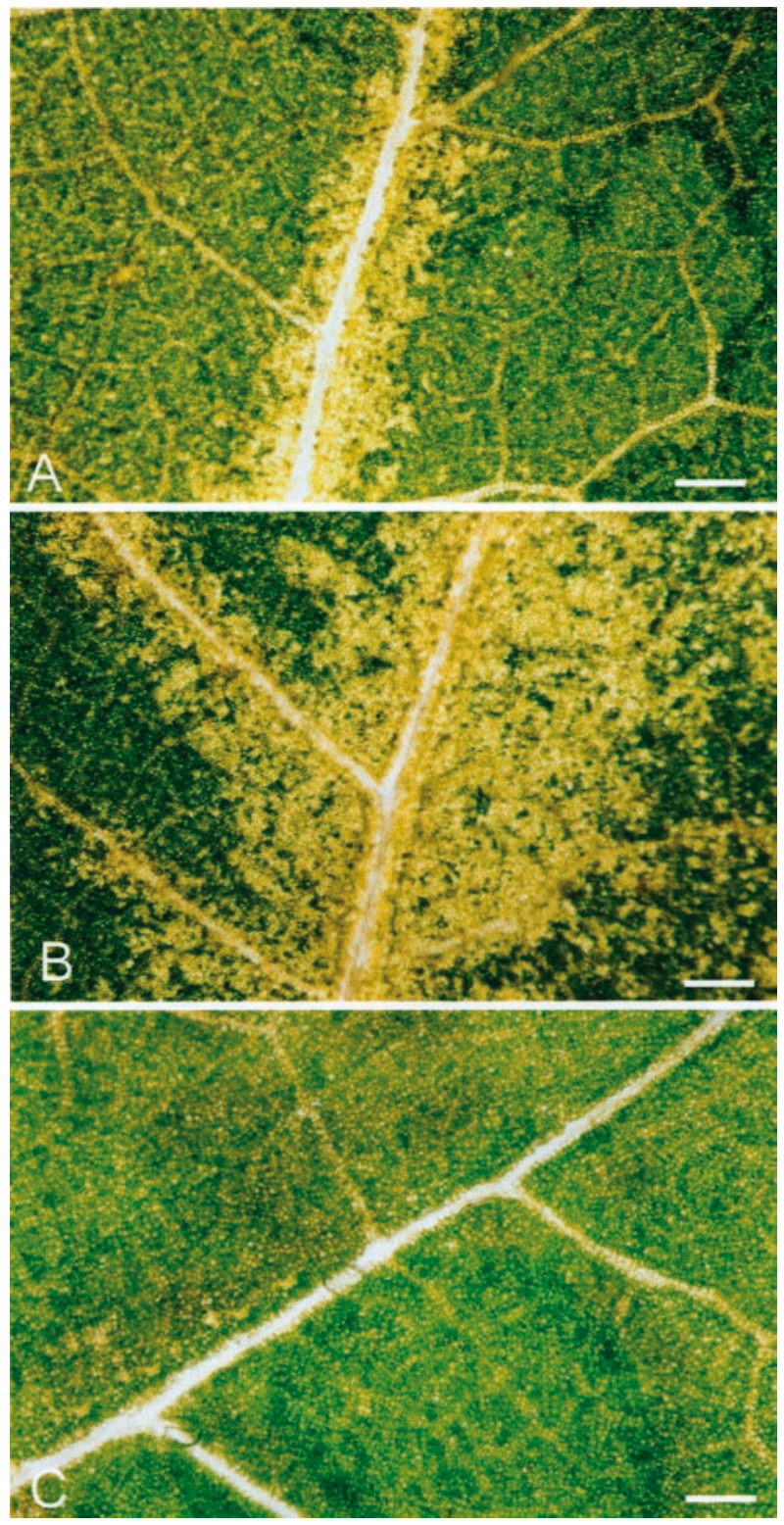

Figure 1. Early symptoms on currant tomato leaves irradiated with UV-C as observed by bright field light microscope.

A. Narrow chlorotic areas are already visible nearby the main vein at $12 \mathrm{~h}$ after exposure. These areas enlarge in the next $12 \mathrm{~h}$ and involve also 2nd order veins (B). C. Non-irradiated control. The bar corresponds to $500 \mu \mathrm{m}$.

ter irradiation, while no staining was found in the non-irradiated samples (Fig. 2D). At the same time, some of these cells were also DAPI-positive (Fig. $2 \mathrm{E})$, indicating the presence of nuclear injury coincident with $\mathrm{H}_{2} \mathrm{O}_{2}$ localization sites and chlorotic lesion areas. Control tissues were DAPI-negative (Fig. 2F).

\section{UV-C irradiation of protoplasts}

On the basis of the previous results, also protoplasts were exposed to the UV-C irradiance of
0.039 watt $\cdot \mathrm{m}^{-2} \cdot \mathrm{s}$ for $2 \mathrm{~h}$. Their viability was estimated with the use of FDA as a vital exclusion dye. FDA can pass through the plasma membrane and then intracellular esterases of viable cells (Fig. 3A) cleave off the diacetate group, producing a highly green-yellow fluorescent compound (Fig. 3B). Protoplasts which do not possess an intact membrane or an active metabolism (Fig. 3C) cannot accumulate the fluorescent product, and therefore do not exhibit the yellow-green fluorescence (Fig. 3D). Our results showed that a UV-C dose of 0.039 watt $\cdot \mathrm{m}^{-2} \cdot \mathrm{s}$ for $2 \mathrm{~h}$ affected protoplast viability in a time-dependent manner (Fig. 4). Following UV-C irradiation, the percentage of viable protoplast dropped already $1 \mathrm{~h}$ after treatment, namely from $97.42 \pm 2.12 \%$ to $43.38 \pm 4.21 \%$. Afterwards, the viability declined slowly to $40.16 \pm 7.25 \%$ at $2 \mathrm{~h}$, to $38.31 \pm 6.94 \%$ at 4 $\mathrm{h}$, and, finally, to $36.46 \pm 1.84 \%$ at $6 \mathrm{~h}$ after the exposure. Almost all non-irradiated protoplasts remained alive, at least up to $6 \mathrm{~h}$ after irradiation.

Nuclear staining with the plasma membranepermeable DAPI correlated with the viability detected by FDA. In fact, the FDA-positive protoplasts were generally DAPI-negative, as viable protoplasts tend to exclude the dye from their nuclei (Fig. 3E), while the FDA-negative ones were DAPI-positive (Fig. 3F), indicating a damage to the nuclear membrane as well.

\section{The comet assay}

To examine the DNA damage in L. pimpinellifolium by SCGE, three different treatments were performed on the protoplasts. They were irradiated with UV-C light or treated with $\mathrm{H}_{2} \mathrm{O}_{2}$ (positive control), or irradiated and treated to asses the cumulative effects of these stresses. Soon after irradiation, or $6 \mathrm{~h}$ later, the protoplasts were embedded in agarose and subjected to denaturation (lysis) and electrophoresis under alkaline conditions. DNA affected by genotoxic agents, i.e. UV-C and $\mathrm{H}_{2} \mathrm{O}_{2}$, migrated from the nuclei toward the anode, giving characteristic cometlike patterns (Figs. 5A, B). The extent of DNA injury was evaluated as the proportion of DNA migrating in the comet tail (\% DNA in tail, Fig. 5D).

Soon after UV-C irradiation or $\mathrm{H}_{2} \mathrm{O}_{2}$ treatment no significant differences were found in DNA migration in comparison to untreated controls (not shown). However, $6 \mathrm{~h}$ later this migration appeared greatly enhanced in the irradiated samples, with the percentage of DNA in the tail of $75.37 \pm 3.74 \%$ (Figs. $5 \mathrm{~A}, \mathrm{D}$ ). Similarly, oxidative stress by $\mathrm{H}_{2} \mathrm{O}_{2}$ produced $71.59 \pm 5.52 \%$ DNA in tail (not shown), while the untreated control showed very low DNA migration (7.88 $\pm 5.58 \%$ ) (Fig. 5D), possibly as a consequence of protoplast isolation procedure. The difference between the $\mathrm{H}_{2} \mathrm{O}_{2}$ 

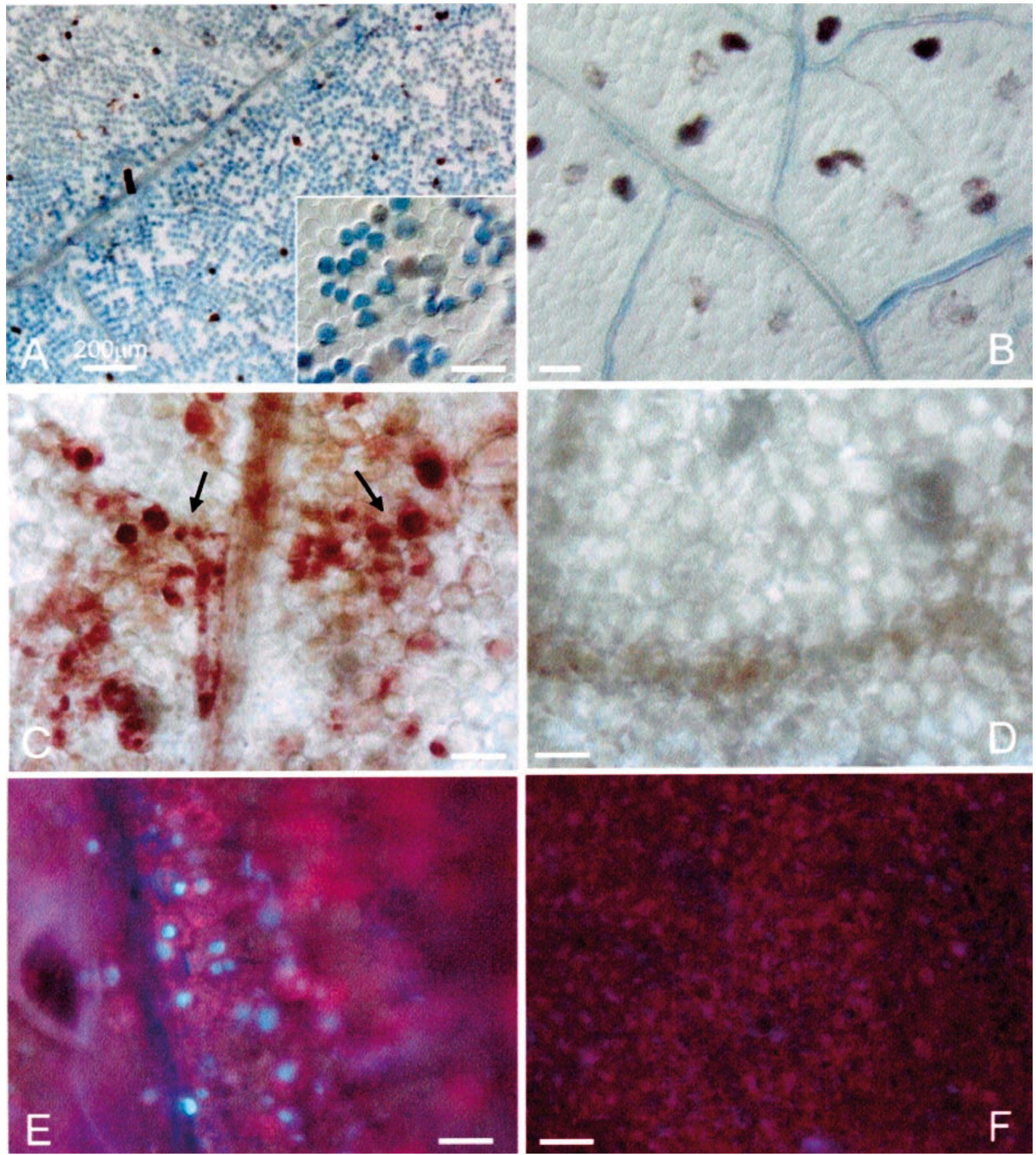

Figure 2. Histo-cytochemical analysis of symptoms.

Currant tomato leaf fragments irradiated with UV-C (254 nm, 0.039 watt $\cdot \mathrm{m}^{-2} \cdot \mathrm{s}$ for $\left.2 \mathrm{~h}\right)(\mathrm{A}, \mathrm{C}, \mathrm{E})$ and non-irradiated, as negative control (B, D, F). A. Dead cells, stained dark blue by Trypan at $24 \mathrm{~h}$ after irradiation, are those of the palisade mesophyll (see enlargement in the inset). $\mathrm{H}_{2} \mathrm{O}_{2}$ deposits, visible as brownish DAB precipitates at $12 \mathrm{~h}$ after irradiation (C, arrows), are mainly localized in the same tissue, preferentially along main veins. DAPI fluorescence (E) of damaged nuclei is visible at $12 \mathrm{~h}$ after irradiation, in palisade mesophyll cells, along veins. Non-irradiated tissues are not stained by Trypan (B), DAB (D) or DAPI (F). The bar corresponds to $100 \mu \mathrm{m}$, if not stated otherwise.

treated and UV-C exposed protoplasts was not statistically significant even at this time, while the oxidative stress combined with UV-C irradiation slightly enhanced the DNA damage (Figs. 5B, D), by $13 \pm 4.11 \%$ of DNA in tail. This value, though statistically significant $\left(P^{*}<0.05\right)$, did not represent a fully additive effect or a synergistic response to the two different stresses.

\section{DISCUSSION}

The use of floating leaf fragments proved to be a reliable and simple technique to perform a homogeneous tissue irradiation and to screen different treatment conditions. With this system we showed that UV-C injury could be detected in currant tomato even before the appearance of visible foliar symp- 
toms, on the basis of distinctive features of leaf parenchyma, namely dead cell distribution and $\mathrm{H}_{2} \mathrm{O}_{2}$ deposit localization. In previous works, we validat- ed a similar histo-cytochemical analysis for the detection of ozone damage in different bean cultivars, as well as in L. pimpinellifolium (Iriti \& Faoro, 2003;
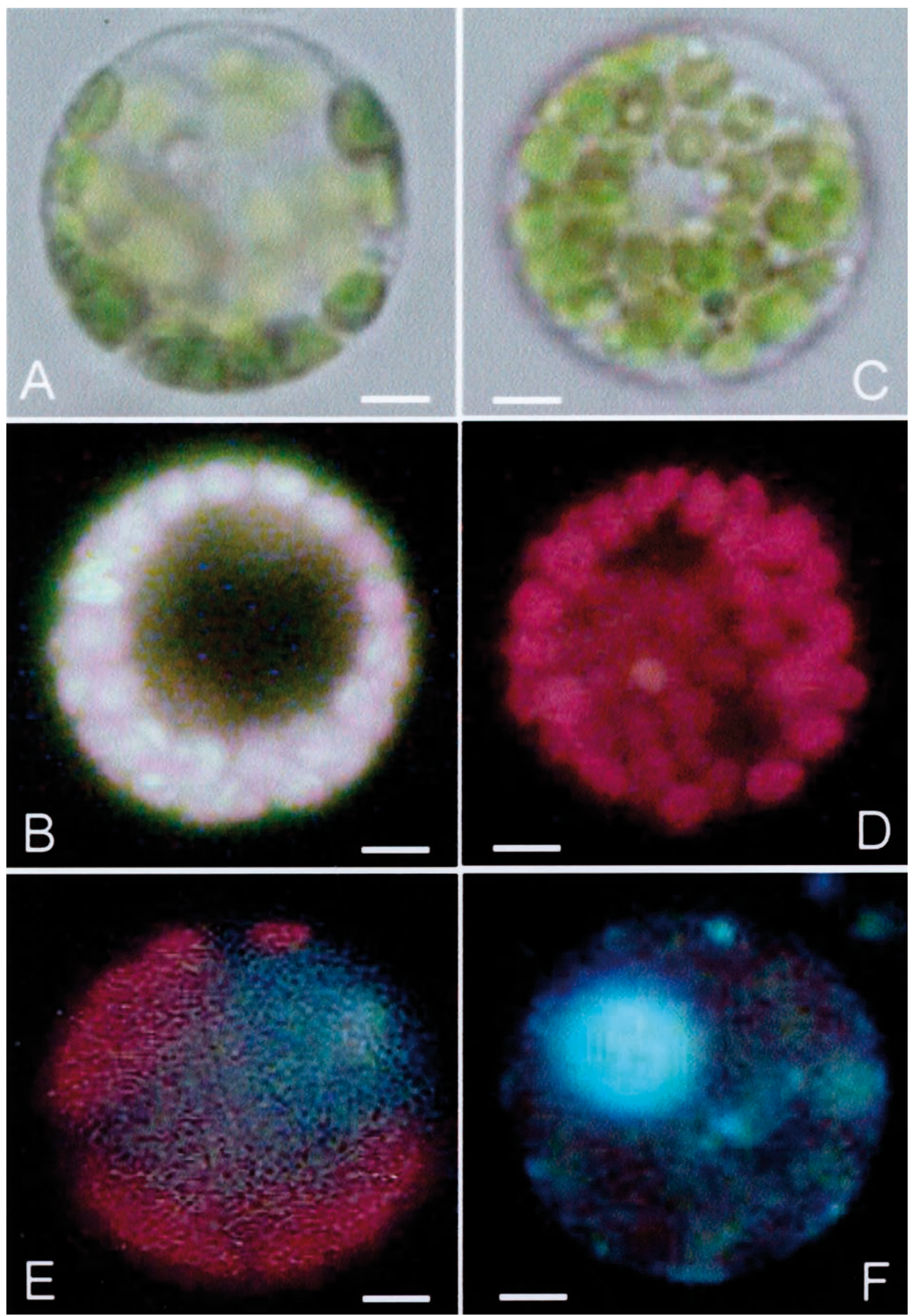

Figure 3. Currant tomato protoplasts non-irradiated, as negative control (A, B, E), and irradiated as above, at $1 \mathrm{~h}$ after irradiation $(C, D, F)$.

A. Control viable protoplast showing a well defined membrane and a typical peripheral localization of chloroplasts. Viable protoplasts become bright yellow fluorescent after treatment with fluorescein diacetate (FDA) (B). C. Non-viable protoplast showing undefined cell membrane and chloroplast aggregation. D. Non-viable protoplasts are red, due to chlorophyll autofluorescence that is not masked by fluorescein fluorescence as in viable ones (B). E. DAPI-negative nuclear staining in a viable protoplast and a DAPI-positive nucleus in a non-viable protoplast (F); in the latter the bright DAPI fluorescence of the damaged nucleus masks the red chlorophyll autofluorescence. The bar corresponds to $10 \mu \mathrm{m}$. 


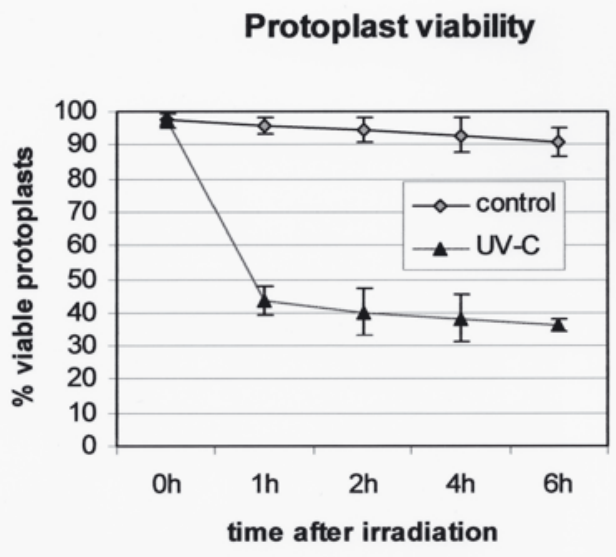

Figure 4. Cell viability assessed by fluorescein diacetate (FDA) in control and in irradiated currant tomato protoplasts at different times after irradiation.

At least 500 protoplasts were counted in three replicate slides for each sample. Data are expressed as percent means of viable protoplasts \pm S.D.

Iriti et al., 2003; Faoro \& Iriti, 2005). However, the mesophyll hallmarks (dead cells and $\mathrm{H}_{2} \mathrm{O}_{2}$ ) showed a different distribution in $\mathrm{O}_{3}$-fumigated currant tomatoes compared to UV-C irradiated ones, being in the latter mainly associated with the periveinal mesophyll regions, at least shortly after exposure. Despite the slightly different localization of the damage in the same tissues, currant tomato appears sensitive to UV-C in the same manner as to ozone, this sensitivity being correlated with the accumulation of a high level of $\mathrm{H}_{2} \mathrm{O}_{2}$ that, in turn, would cause cell death. Considering that plant tolerance to environmental stresses is mainly due to the exclusion of their damaging effects, as a result of cellular and apoplastic antioxidant defense mechanisms, it seems that these defenses are rather limited in currant tomato, as confirmed by previous studies on its antioxidant compounds (Dubbels et al., 1995; Antonius et al., 2003).

Cell death observed in mesophyll cells is quite likely a consequence of an apoptotic process, rather than a necrotic one, according to previous studies on plant cells (Danon \& Gallois, 1998), and the comet assay we performed on protoplasts confirmed this hypothesis. In fact, we found intense DNA fragmentation at $6 \mathrm{~h}$ but not at $0 \mathrm{~h}$ after irradiation, suggesting that the consistent drop of protoplast viability observed with FDA soon after treatment is related to the physical effect of UV-C on the cell membrane, leading to instantaneous fluorescein release, rather than to direct DNA damage. This is in agreement with a previous observation performed with Southern blot and TUNEL analysis of DNA from Arabidopsis protoplasts irradiated with UV-C (Danon \& Gallois, 1998). It should be noted that those authors

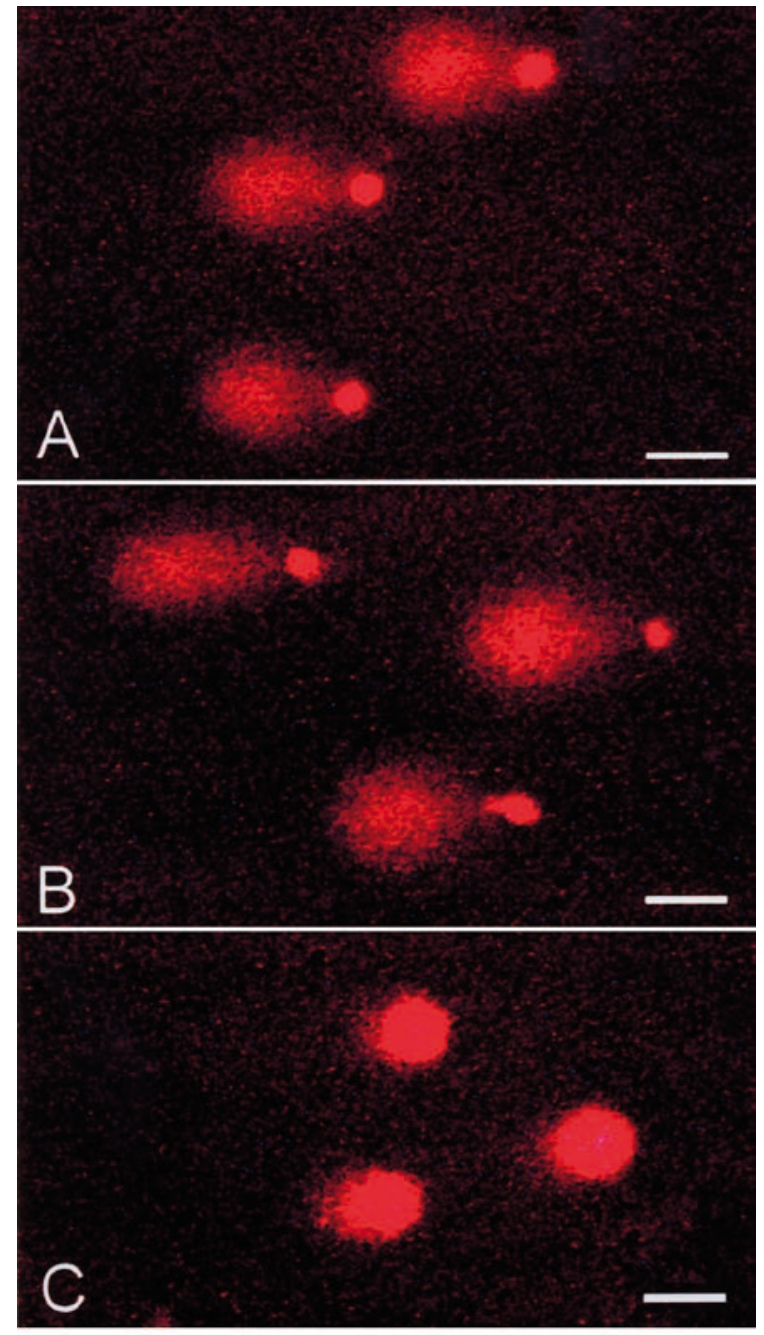

Comet assay

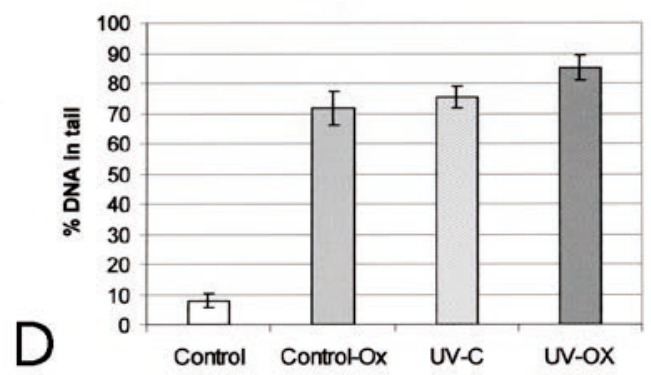

Figure 5. Comet assay of currant tomato protoplasts. Protoplasts $6 \mathrm{~h}$ after UV-C irradiation (A, B). Non-irradiated control $8 \mathrm{~h}$ after isolation (C). A. In UV-C irradiated protoplasts the amount of DNA in the tail is comparable to that obtained with an oxidative stress by $\mathrm{H}_{2} \mathrm{O}_{2}$ treatment (not shown). B. In UV-C irradiated and $\mathrm{H}_{2} \mathrm{O}_{2}$-treated samples the amount of DNA in the tail is only slightly higher. C. In non-irradiated protoplast DNA does not migrate. The bar corresponds to $20 \mu \mathrm{m}$. D. Percentage of DNA migrating in the tail of non-irradiated (control), $\mathrm{H}_{2} \mathrm{O}_{2}$-treated (control-Ox), irradiated (UV-C), irradiated and $\mathrm{H}_{2} \mathrm{O}_{2}$ treated (UV-Ox) protoplasts. Irradiated protoplasts were examined $6 \mathrm{~h}$ later. Data are expressed as means \pm S.D. and statistical analysis performed with Duncan test (different letters represent significantly different means, $\left.P^{*}<0.05\right)$. 
employed higher UV-C doses than we did to induce apoptosis and, possibly as a consequence, Arabidopsis protoplast viability dropped more quickly than in currant tomato. Nevertheless necrotic cell death did not occur even in that case.

Comet assay on leaf tissues was used before to investigate ozone stress in Nicotiana tabacum cultivars Bel B and Bel W3 (Restivo et al., 2002), the effect of ionizing radiation in bean cultivars (Khan et al., 2002), as well as for environmental monitoring in Allium cepa and Impatients balsamina tissues of an array of genotoxic pollutants, such as ozone, benzene and nitrogen oxides (Poli, 1999).

In conclusion, we showed that UV-C injury can be easily detected in vivo with a simple histocytochemical technique, also in the absence of visible symptoms, and investigated in vitro with the comet assay. This integrated approach for the study of genotoxic agents can be performed either on nuclei isolated from tissues or directly on protoplasts (Gichner \& Mühlfeldová, 2002). The former DNA is probably gentler on, while in the case of protoplasts the enzymatic digestion of the walls may lead to slight DNA damage, as we observed in the untreated controls. This problem could be overcome by testing different digestion methods. In any case, the great advantage of harvesting a huge number of nuclei from protoplasts, thus ameliorating the statistical significance of the comet assay, is certainly a major benefit by itself.

\section{REFERENCES}

Antonius GF, Hawkins LM, Kochhar TS (2003) Foliar phenolic variation in wild tomato accession. Bull Environ Contam Tox 70: 9-16.

Buschmann H, Reilly K, Rodriguez MX, Tohme J, Beeching JR (2000) Hydrogen peroxide and flavan-3-ols in storage roots of cassava (Manihot esculenta Crantz) during postharvest deterioration. J Agic Food Chem 48: 55225529.

Cleaver JE (2006) Cells have long experience of dealing with UVC light. Nature 442: 244.

Coohill TP (1989) Ultraviolet action spectra (280 nm to 380 $\mathrm{nm}$ ) and solar effectiveness spectra for higher plants. Photochem Photobiol 50: 451-457.

Danon A, Gallois P (1998) UV-C radiation induces apototic-like changes in Arabidopsis thaliana. FEBS Lett 437: 131-136.

de Wit PJGM, Brandwagt BF, van der Burg HA, Cai X, van der Hoorn RAL, de Jong CF, van't Looster J, de Kock MJD, Kruijt M, Lindhout WH, Luderer R, Takken FLW, Westerink N, Vervoort JJM, Joosten MHAJ (2002) The molecular basis of co-evolution between Cladosporium fulvum and tomato. Antonie van Leeuwenhoek 81: 409-412.

Dubbles SR, Reiter RJ, Klenke E, Goeble A, Schnakenberg E, Ehlers C, Schiwara HW, Schloot W (1995) Melatonin in edible plants identified by radioimmunoassay and by high performance liquid chromatography. J Pineal Res 18: 28-31.

Faoro F, Iriti M (2005) Cell death behind the invisible symptoms: early diagnosis of ozone injury. Biol Plant 49: 585-592.

Gichner T, Mühlfeldová Z (2002) Induced DNA damage measured by Comet assay in 10 weed species. Biol Plant 45: 509-516.

Hollósy F (2002) Effects of ultraviolet radiation on plant cells. Micron 33: 179-197.

Husain SE, James C, Shields R, Foyer C (2001) Manipulation of fruit sugar composition but not content in Lycopersicon esculentum fruit introgression of an acid invertase gene from Lycopersicon pimpinellifolium. New Phytol 150: 65-72.

Iriti M, Faoro F (2003) Benzothiadiazole (BTH) induces cell-death independent resistance in Phaseolus vulgaris against Uromyces appendiculatus. J Phytopathol 151: 171180.

Iriti M, Rabotti G, De Ascensao A, Faoro F (2003) BTHinduced resistance modulates ozone tolerance. J Agric Food Chem 51: 4308-4314.

Iriti M, Belli L, Nali C, Lorenzini G, Gerosa G, Faoro F (2006) Currant tomato (Lycopersicon pimpinellifolium sensitivity to ozone injury and its possible role as bioindicator. Environ Poll (in press).

Jung C, Cai G, Kleine M (1998) Engineering nematode resistance in crop species. Trends Plant Sci 3: 1360-1385.

Khan AA, Khan HM, Delincée H (2002) Detection of radiation treatment of beans using DNA comet assay. Rad Phys Chem 63: 407-410.

Koppen G, Verschaeve L (1996) The comet test on plant cells: a new genotoxicity test for DNA strand breaks in Vicia faba root cells. Mutat Res 360: 193-200.

Kovács E, Keresztes Á (2002) Effect of gamma and UV- B/ C radiation on plant cells. Micron 33: 199-210.

Montreal Protocol (1987) http://hquneporg/ozone/Treaties_ and_Ratification/2B_montreal_protocolasp.

Navarrete $\mathrm{MH}$, Carrera P, de Miguel M, de la Torre C (1997) A fast comet assay for solid tissue cells. The assessment of DNA damage in higher plants. Mutat Res 389: 271-277.

Palyvoda O, Polanska J, Wygoda A, Rzeszowska-Wolny J (2003) DNA damage and repair in lymphocytes of normal individuals and cancer patients: studies by comet assay and micronucleus tests. Acta Biochim Polon 50: 181-190.

Pico B, Ferriol M, Diaz MJ, Nuez F (1999) Developing tomato breeding lines resistant to tomato yellow curl virus. Plant Breed 118: 537-542.

Poli P (1999) Comet assay application in environmental monitoring: DNA damage in human leukocytes and plant cells in comparison with bacteria and yeast tests. Mutagenesis 14: 547-556.

Restivo FM, Laccone MC, Buschini A, Rossi C, Poli P (2002) Indoor and outdoor genotoxic load detected by the comet assay in leaves of Nicotiana tabacum cultivars Bel B and Bel W3. Mutagenesis 17: 127-134.

Stapleton AE (1992) Ultraviolet radiation and plants: burning questions. Plant Cell 4: 1353-1358.

Sun Y-L, Zhu H-Z, Zhou J, Dai Y-R, Zhai Z-H (1999) Menadione-induced apoptosis and the degradation of lamin-like proteins in tobacco protoplasts. Cell Mol Life Sci 55: 310-316.

Zhou J, Zhu H-Z, Dai Y-R (1999) Effect of ethrel on apoptosis in carrot protoplasts. Plant Growth Reg 27: 119-123. 